\title{
Pengelolaan Desa Wisata Hutan Mangrove Desa Bedono Kecamatan Sayung Kabupaten Demak
}

\author{
Safa Putri Wulan Sari, Achmad Rifai \\ Jurusan Pendidikan Luar Sekolah FIP Universitas Negeri Semarang \\ safapws@gmail.com, rifaipls@mail.unnes.ac.id
}

Received: 23 Februari 2020; Revised: 27 April 2020; Accepted: 28 April 2020

DOI: http://dx.doi.org/10.37905/aksara.6.2.133-150.2020

\begin{abstract}
Abstrak
Penelitian ini bertujuan mendeskripsikan Perencanaan Program, Pelaksanaan Program dan Pengawasan Program Desa Wisata Hutan Mangrove Desa Bedono Kecamatan Sayung Kabupaten Demak. Pendekatan yang digunakan dalam penelitian ini adalah deskriptif kualitatif. Subyek pada penelitian ini terdiri dari 1 pengelola Desa Wisata, 2 masyarakat Desa Bedono, dan 1 wisatawan Desa Wisata. Pengumpulan data yang digunakan adalah observasi, wawancara, dokumentasi.Teknik keabsahan data menggunakan sumber dan metode.Teknik analisis data menggunakan pengumpulan data, reduksi data, penyajian data, dan penarikan simpulan. Hasil penelitian ini menunjukkan bahwa:Pengelolaan Desa Wisata Hutan Mangrove Desa Bedono dikelola oleh masyarakat lokal yang memanfaatkan potensi daerah Desa Bedono. Pengelolaan dilaksanakan dengan tahapan perencanaan, pelaksanaan dan pengawasan yang seluruh masyarakat Desa Bedono ikut berpartisipasi dalam berjalannya pengelolaan Desa Wisata Hutan Mangrove Desa Bedono.

Kata Kunci: Pengelolaan, Desa Wisata, Hutan Mangrove.

Abstract This study aims to describe: Program Planning, Program Implementation and Supervision of the Mangrove Forest Tourism Village Program Bedono Village Sayung District Demak Regency. The approach used in this research is descriptive qualitative. The subjects in this study consisted of 1 manager of the Tourism Village, 2 Bedono Village communities, and 1 Tourist Tourism Village. Data collection used is observation, interview, documentation. Data validity techniques using sources and methods.Data analysis techniques using data collection, data reduction, data presentation, and drawing conclusions. The results of this study indicate that: Management of the Mangrove Forest Tourism Village Bedono Village is managed by local communities who utilize the potential of the Bedono Village area. Management is carried out with the stages of planning, implementation and supervision that all the people of Bedono Village participated in the management of the Mangrove Forest Tourism Village of Bedono Village.
\end{abstract}

Keywords: Management, Tourism Village, Mangrove Forest. 


$\begin{array}{ll}\text { Volume } & : 06 \\ \text { Nomor } & : 02 \\ \text { Bulan } & : \text { Mei } \\ \text { Tahun } & : 2020 \\ \text { http } & : / / \text { ejurnal.pps.ung.ac.id/index.php/AKSARA/index }\end{array}$

\section{PENDAHULUAN}

Indonesia adalah negara kepulauan yang sangat luas, didalamnya terdapat berbagai pulau, suku, ras, adat istiadat, dan bahasa yang beragam, begitu juga sumber saya alamnya yang sangat melimpah.Sumber daya yaitu sesuatu yang mempunyai nilai guna.Sedangkan Sumber Daya Alam (SDA) ialah semua faktor fisik, kimia, biologi dan sosial yang membentuk lingkungan disekitar kita. Hutan Mangrove sangat diperlukanoleh masyarakat pesisir, karena dapat melindungi daerah mereka saat air sedang pasang dan angin yang sangat kencang.Pariwisata dengan pengelolaan oleh warga selalu mengutamakan pendekatan bottom-up, dan wisata yang berkelanjutan selalu mengutamakan pendekatan top-down. Dapat diartikan bahwa "penelitian telah menetapkan bahwa anggota masyarakat dapat terlibat dan berpartisipasi dalam proses dan mekanisme pemberdayaan masyarakat. Konsep warga Negara yang aktif sangat berarti dan ada penduduk setempat bahkan masyarakat yang paling lemah yangantusias atas kesempatan untuk mempengaruhi masa depan lingkungan setempat".

Telah diidentifiikasi bahwa mereka memerlukan dukungan agar dapat menggapai partisipasi dapat diartikan dengan sektor publik serta dukungan itu dapat mewakili SDM yang hebat jika pemberdayaan yang akan berikan pada semua warga kita" (Hajaroh dan Mulyono, 2014:30). Untuk memberikan semangat program di masyarakat agar tercapai suatu keinginan yangmana keinginan tersebut adalah keinginan semua warga. Dengan ini, dibentuklah kelompok agarmengabulkankehendak masyarakat yang akan didapat. Kelompok juga memerlukan agarkomunikasi seluruh sumber yang ada guna memperoleh hasil yang diinginkan (Kisworo, 2014:46).

Sururi (2018:2) mengemukakan Pengelolaan Desa Wisata dari bawah (bottom up) menjadikan warga agarinisiatif dari merencanakanmenggunakan asumsi jika masyarakat mempunyaitingkat kemampuan untuk mencari permasalahan dan kebutuhan jugastrategi yang paling sesuai dengan keadaan masyarakat. Sesungguhnya pengelolaan Wisata ialah kegiatan yang mempunayi maksud agar sesuai tujuan wisata secara bertahap dari segi ekonomi, adat istiadat serta lingkungan dan pengelola harus melaksanakan pengelolaan sumberdaya yang efektif (Priatna dan Diarta, 2009:89). Berdasarkan latar belakang diatas maka akan dilakukan sebuah penelitian tentang Pengelolaan Program Desa Wisata Hutan Mangrove Desa Bedono Kecamatan Sayung Kabupaten Demak yang melibatkan partisipasi masyarakat dalam setiap kegiatan Pariwisata.

Menurut UU No 1 Tahun 2014 mengenai pengelolaan Wilayah Pesisir serta Pulaupulau kecil, perencanaan pengelolaan ialah rencana yang terdapat susunan keraangaka kebijakan, cara, dan tanggungjawab untukmengkoordinasi penentuan kebijakandi berbagai lembagapemerintah tentang kesepakatan penggunaansumber daya atau kegiatan pembangunan di zona yang ditentukan (Suwandono, 2015:53).

Gluek \& Jauch (dalam Saladin, 1994:4) mengemukakan :

"Strategic management is a stream of the decisions and actions which leads to development of an effective strategy or strategies to help achieving objectives . 


$\begin{array}{ll}\text { Volume } & : 06 \\ \text { Nomor } & : 02 \\ \text { Bulan } & : \text { Mei } \\ \text { Tahun } & : 2020 \\ \text { http } & : / / \text { ejurnal.pps.ung.ac.id/index.php/AKSARA/index }\end{array}$

The strategy management process is the way in which strategic determined objectives and make strategic decisions".

Manajemen strategik ialah arah kebijakan serta perlakuan yang mengarah pada pengembangaan di strategi secara efektif agar dapat tercapai sesuai target. Proses manajemen strategi ialah suatu strategi dengan jalan bagaimana para perencana strategi memutuskan sasaran serta membuat kesimpulan strategi.Pernyataan Conyers dkk dalam Munir (2002:23) menjelaskan perencanaan sebagai suatu proses yang berhubungan didalamnya terdapatkeputusan atau kebijakan atau pilihan-piliihan dengan beragam jalan terbaik menggunakan sumberdaya agarterwujud tujuan-tujuan yang terjadi di masa depan (Suwandono, 2015:52).

Dalam proses manajemen diperlukan adanya pengorganisasian, dalam hal ini Desa Wisata terfokus pada pengorganisasian masyarakat yang senada dengan jurnal internasional tentang International Journal of Educational Development : Shifting the perspective on community-based management of education: From systems theory to social capital and community empowerment Yang menjelaskan bahwa:

"Community organizing literature helps to think about how to develop the social capital necessary for CBM initiatives while also highlighting their shortcomings, that is, while pointing to the need to go beyond technical and narrowly-focused forms of community involvement".

Literatur pengorganisasian masyarakat membantu untuk berpikir tentang bagaimana mengembangkan modal sosial yang diperlukan untuk inisiatif CBM sambil juga menyoroti kekurangan mereka, yaitu, sambil menunjukkan perlunya melampaui bentuk-bentuk keterlibatan masyarakat yang teknis dan terfokus secara sempit (Edwards Jr, 2019:19).

Proses Manajemen ada 3 tahap yaitu perencanaan, pelaksanaan dan pengawasan: perencanaan ialah tujuan suatu kelompok, untuk menetapkansemua cara agar tercapai tujuannys, serta menambahkan rencana guna mengintegrasikaan dan komunikasi di suatu program kegiatan.

Tahapan selanjutnya ialah tahap pelaksanaan. Pelaksanaan bisa dimaknai dengan kegiatan koordinasi dari sumber daya, tugas, antar anggota supaya tujuan dapat tercapai secara efisien dan efektif. Kebijakan ialah pegangan pelaksanaan untuk tindakan yang sesuai dengan cara meraih suatu tujuan dan sasaran. Kebijakan pimpinan berbentuk aturan di bidang publik, teknis, alokasi sumber-daya kelompok, pelayanan masyarakat, antara lain adalah: wewenang/tanggung jawab pengelola, Dokumentasi beragam pola kerja untuk tiap tahapan pengelolaan yangmana revisi penyebaran ataupun dibatalkan agar dimudahkan tindakan yang dicek dan juga mencegah yang tidak diginkan. Koordinasi secara dalam dan luar, Pengadaan (prourement), Mengendalikan tahap supaya keluaran sesuai dengan perencanaan dan tingkat target (yang termasuk: instruksi tugas, sarana-prasarana, perawatan,lingkungan kerja)., Inspeksi, menguji dan tindakan dicek maupun mengurangi hal-hal yang tidak diinginkan, Pelatihan staff agar meningkatkan kedisiplinan dan keahliannya, Jaminan pelayanan prima (kebijakan 


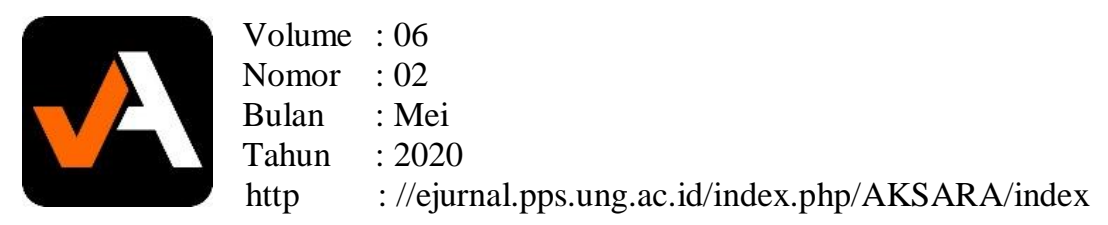

publik), Dibutuhkan chek list kelengkapan aturan kelompok tersebut (Akdon, 2011:187). Tahap paling akhir dari tahapan manajemen adalah pengawasan.Pengawasan bermaksud mengamati apakah kegiatan kelompok sesuai dengan rencana.Pengelola wajib mengawasi kemajuan kelompok. Nurhalim (2014:49) Mengemukakan Evaluasi adalah suatu proses untuk mengumpulkan dan menganalisis data atau informasi agar dapat mengetahui tingkat pencapaian tujuan suatu kegiatan/program. Mulyono (2015:88) Evaluasi dan monitoring adalah suatu program yang dilaksanakan guna mengetahui program dengan terencana serta untuk mengetahui tingkat kesuksesan suatu program.

Desa Wisata ialah suatu daerah pedesaan yang memberikan keasliannyayang dilihat dari segiadat istiadat, ekonomi, sosial, keseharian, bangunan tradisional, strukturgedung desa yang ada dalam rangkaian gabungan komponen wisata yaitu atraksi, akses jalan, transportasi dan sarana prasarana (Zakaria dan Suprihardjo, 2014:246). Heni (2013:131) mengemukakan bahwa Desa wisata adalah bentuk pelaksanaan pembangunan wisata berbasis masyarakat secara berkelanjutan. Dengan adanya Desa Wisata akan menjadi produk wisata lebih bernilai dengan budaya desa tanpa merusaknya. Ada satu hal yang dapat memberikan kesanuntuk menciptakan suatu daerah wisata adalahdisesuaikan adat istiadat budaya lokal di daerah tersebut. Keadaan ini yang menjadikandibentuknya kegiatan wisata di suatu desa karena ciri khas adat istiadatwarga yang tinggal di lingkungan tersebut.

MelaksanakanpengelolaanWisata harus diadakan pembuatan produk lokal untuk menerapkan wisata berawasan lingkungan. Muljadi (2009: 27), mengemukakan desa Wisata ialah suatu suguhan Wisata didalamnyawarga desa nya berpartisipasi dengan seluruh bagian yang ada.Desa Wisata bukan hanya mempengaruhi pereekonomian masyarakat, tetapi juga bisa mengkonservasiekosistem dan adat istiadat masyarakat setempat yang paling penting mengenai nilai-nilai kebersamaan, kekeluargaan, gotongroyong, dan lain-lain.Maka dengan ini, kelestarian lingkungan dan sosial adat istiadat masyarakat akan menjadikan daya tarik bagi Wisatawan yang melakukan perjalanan Wisata.

CBT (Community Bassed Tourism) adalah konsep pengelolaan wisata dengan pemberdayaan warga setempat, yangmana warga ikut partisipasi di perencanaan, pelaksanaan serta memberi pendapat untuk suatu hasil putusan di pengelolaannya. Mempunyai 3 kegiatan iwisata yang menunjang konsep CBT yaitu menjelajah, Wisata adat istiadat, wisata alam. Menurut Bank Dunia Konsep CBT mempunyai peran di masyarakat dalam langkah memutuskan suatu keputusan yangmana berhubungan dengan peningkatan pendapatan, peluang kerja dan juga menjaga keutuuhan lingkungan serta adat istiadat yang ada, yang mana akan meningkatkan jatidiri serta kesenangan dari masyarakat yang ada.

Bentuk pengelolaan desa Wisata semestinya ialah milik warga yang dikelola secara benar dan baik, segalapertimbangan ada aspek penting untuk pengelolaan yaitu ; (1) aspek SDM, (2) aspek pendanaan, (3) aspek material, (4) aspek pengelolaan dan (5) aspek pasar. Dalam lingkupkelompok masyarakat yang berbentuk kemitraan, pengelolaan korporasi, yayasan atau badan pengelola desa Wisata yang unsur-unsur 


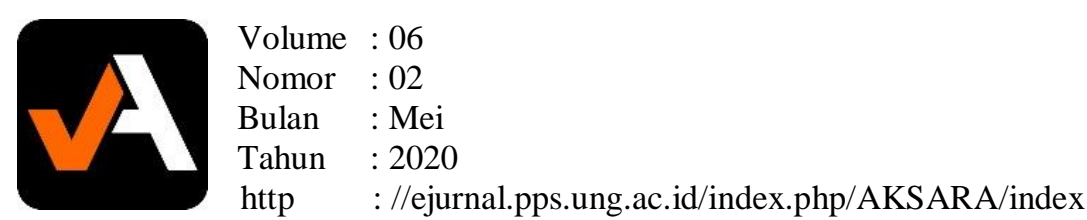

pengelolaannya didapatkan dari keahlian masyarakat setempat dan lebih mengutamakanpartisipasi para pemuda yang mempunyai latar belakang pendidikan serta keterampiilan yang di butuhkan (Sastrayuda, 2010).

Menurut Choibamroong dalam (Aunkrisa Sangchumnong, 2018:2) :

"More recent models have been based on the integration of the tourism and creative industries as a whole, engaging not only consumers but also producers, policy makers, and knowledge institutions as well as related industrie".

"Model yang lebih baru didasarkan pada integrasi Pariwisata dan kreatif industri secara keseluruhan, melibatkan tidak hanya konsumen tetapi juga produsen, pembuat kebijakan, dan lembaga pengetahuan serta industri terkait".Pengelolaan sumberdaya wisata ialahsuatu cara agar dapat menggapai tujuan wisata yang berkelanjutan secara sosial, pendapatan, dan ekosistem, jadi pengelolaharus melaksanakanpengelolaan sumberdaya yang efektif. Pengelolaan sumberdaya dilaksanakan guna menjaamin keutuhan lingkungan dan degradasi kualitas ekosistem (Hakim, 2016: 17).

Pengelolaan program Desa Wisata berbasis masyarakat yang digunakan sesuai dengan jurnal internasional tentang Journal of Destination Marketing \& Management: Destination management in New Zealand: Structures and functions Yang menjelaskan bahwa:

"These functions need to be seen in the context of the broader purpose and role of local authorities in New Zealand. Local govern- ment is subject to national legislation which has been frequently amended with an emphasist his century on greater consultation, accountability and efficiency. Under the Local Government Act 2002, TLA swere 'to play abroad role in promoting the social, economic, environmental, and cultural well-being of their communities... [through] the prudent use and stewardship of community resources".

"Fungsi-fungsi ini perlu dilihat dalam konteks tujuan dan peran otoritas lokal yang lebih luas di Selandia Baru.Pemerintah daerah tunduk pada undang-undang nasional yang telah sering diamandemen dengan penekanan pada abadnya tentang konsultasi, akuntabilitas, dan efisiensi yang lebih besar.Di bawah Undang-Undang Pemerintah Daerah 2002, TLA berperan 'untuk memainkan peran di luar negeri dalam mempromosikan kesejahteraan sosial, ekonomi, lingkungan, dan budaya masyarakat mereka ... [melalui] penggunaan yang bijaksana dan pengelolaan sumber daya masyarakat (Pearce, 2015:7).

\section{METODE PENELITIAN}

Pendekatan yang digunakan dalam penelitian dan perencanaan ini adalah pendekatan kualitatif.Analisis yang dilakukan adalah analisis deskriptif kualitatif.Dengan metode pengumpulan data observasi dan wawancara mendalam. Wawancara mendalam dilakukan untuk menggali informasi sedbanyakbanyaknya.Penelitian Pengelolaan Desa Wisata Hutan Mangrove mengambil lokasi di Desa Bedono Kecamatan Sayung Kabupaten Demak. Alasan mengambil lokasi ini 
karena adanya kesesuaian antara permasalahan dengan objek penelitian. Desa Wisata Hutan Mangrove Desa Bedono Kecamatan Sayung Kabupaten Demak menjadi salah satu destinasi Wisata yang menarik. Dengan pengelolaan berbasis masyarakat lokal menjadikan Desa Wisata Hutan Mangrove Desa Bedono terus berjalan.Subjek penelitian ini adalah Pengelola Desa Wisata Hutan Mangrove Desa Bedono 1 orang, dan masyarakat Desa Bedono 2 orang dan Wisatawan Desa Wisata Hutan Mangrove Desa Bedono 1 orang.

Observasi penelitian ini dilakukan dengan mengamati lingkungan , pengelolaan dan partisipasi masyarakat dalam mengelola Desa Wisata Hutan Mnagrove Desa Bedono. Metode ini digunakan untuk memperoleh data penelitian yang meliputi perencanaan, pelaksanaan dan pengawasan Desa Wisata Hutan Mangrove Desa Bedono kecamatan Sayung Kabupaten Demak. Peneliti melakukan wawancara dengan Pengelola Desa Wisata Hutan Mangrove Desa Bedono, masyarakat yang berpartisipasi, dan Wisatawan Desa Wisata Hutan Mangrove Desa Bedono. Dokumentasi dilakukan untuk mendapat foto keadaan Desa Wisata Hutan Mangrove Desa Bedono, Struktur Organisasi Kelompok Mangrove Bahari Desa Bedono, Kegiatan penanaman Hutan Mangrove, dokumentasi dengan subjek maupun informan dan pengambilan video Desa Wisata Hutan Mangrove Desa Bedono.Penelitian pengelolaan Desa Wisata Hutan Mangrove di Desa Bedono ini adalah dengan cara triangulasi sumber dan metode pengumpulan data. Triangulasi sumber berupa Hasil wawancara Pengelola Desa Wisata Hutan Mangrove, masyarakat Desa Wisata Hutan Mangrove dan wisatawan Desa Wisata Hutan Mangrove Desa Bedono. Triangulasi metode adalah pengumpulan data dengan observasi, wawancara, dan dokumentasi. Teknik pemeriksaan keabsahan data yang digunakan dalam penelitian ini adalah teknik Triangulasi.Dalam Penelitian ini peneliti menggunakan teknik Analisis data kualitatif. Teknik analisis data kualitatif adalah bersifat induktif,suatu analisis berdasarkan data yang diperoleh dan akan dikembangkan pola hubungan tertentu menjadi hipotesis. Berdasarkan hipotesis yang dirumuskan berdasarkan data tersebut, selanjutnya akan mencari data lagi secara berulang. sehingga selanjutnya dapat menyimpulkan apakah hipotesis tersebut diterima atau ditolak berdasar data yang terkumpul. Teknik analisis data dalam penelitian ini menggunakan beberapa tahap yaitu Tahap pengumpulan data, Reduksi data, Penyajian data dan penarikan kesimpulan.

Analisis data merupakan kegiatan mengurutkan dan mengkategorikan sesuai fokus masalah yang akan dijawab. Proses pengumpulan data dilakukan secara sistemastis, dari transkip wawancara, catatan lapangan, dan bahan lain yang di dapat di lapangan. Pengumpulan data penelitian ini meliputi rekapan wawancara, catatan lapangan dan foto kegiatan saat penelitian.Saat melakukan penelitian akan mendapat data yang cukup banyak, oleh karena itu perlu dicatat secara rinci untuk memudahkan dalam memilih mana data yang penting dan mana yang tidak penting. Hal ini tentunya melalui proses analisis data dengan reduksi data. Menurut Sugiyono (2016: 338) mereduksi data berarti merangkum, memilih hal-hal yang pokok, memfokuskan pada hal-hal yang penting, dicari tema dan polanya, dan membuang yang tidak perlu.Dalam penelitian kualitatif, penyajian datadilakukan dalam bentuk uraian singkat, bagan, 


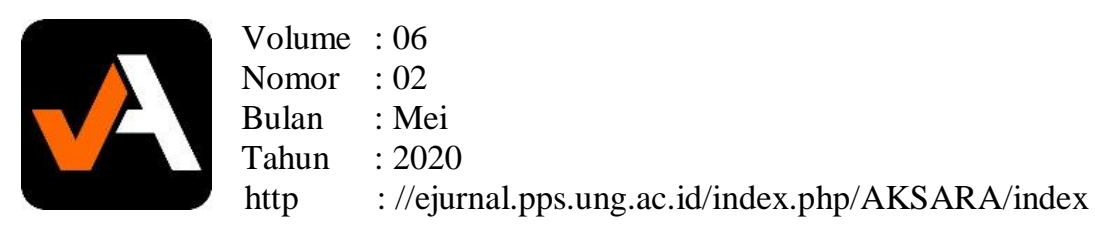

hubungan antar kategori, flowchart dan sejenisnya (Sugiyono, 2016: 341). Penyajian data pada penelitian ini juga menggunakan teks yang bersifat naratif yakni menggunakan uraian verbal tentang pengelolaan Desa Wisata Hutan Mangrove Desa Bedono.

\section{HASIL DAN PEMBAHASAN}

\section{Tahapan Perencanaan Program Desa Wisata Hutan Mangrove Desa Bedono}

Dalam melaksanakan proses perencanaan pembangunan dilaksanakan berdasarkan asas Button Up atau perencanaan berdasarkan usulan yang berasal dari masyarakat berdasarkan skala prioritas, hal ini dilaksanakan dengan melaksanakan Musyawarah Rencana Pembangunan Desa (Musrenbangdes) serta mengadakan Musyawarah Desa (Musdes) yang dilaksanakan untuk mendapatkan masukan dan skala prioritas dalam pembangunan.

Perencanaan pengelolaan pariwisata adalah aktivitas yang dilaksanakan masyarakat Desa Bedono untuk melaksanakan pembuatan daftar pekerjaan apasaja yang akan dilaksanakan oleh masing-masing anggota pada saat ada kegiatan pariwisata. Perencanaan pengelolaan pariwisata juga dapat artikan sebagai aktivitas sharing pemikiran atau konsep untuk mendapat masukan dan mendapatkan dukungan untuk dilaksanakan dalam kegiatan pariwisata. Nurulitha Andini (2013:175) Wisata berbasis masyarakat terlihat bahwa masyarakat membentuk suatu kelompok dan mengelola bisnis wisata sesuai dengan aturan, pembagian atau kewenangan yang sudah di sepakati masyarakat.

Perencanaan Desa Wisata Hutan Mangrove Desa Bedono berawal pada tahun 2004 dengan penanaman pohon mangrove disekitar Desa untuk menyelamatkan Desa Bedono dari abrasi dan mengurangi hentaman ombak yang mengenai rumah masyarakat. Program tersebut melibatkan seluruh masyarakat dengan dibentuknya kelompok tani yang disebut dengan Kelompok Mangrove. Setelah itu penanaman berjalan ternyata hasilnya menyita perhatian masyarakat karena keindahan Hutan Mangrove yang bagus untuk dijadikan spot foto dan hingga sekarang menjadi Desa Wisata yang di datangi oleh masyarakat lokal hingga mancanegara. Wahyurini (2017:44) mengemukakan adanya ekowisata masyarakat diharapkan untuk memanfaatkan sebaik mungkin lingkungan hutan mangrove dengan kekayaan alam yang ada didalamnya.

Mengutip pernyataan Conyers dkk dalam munir (2002:23) mendefinisikan perencanaan seagai proses yang berkesinambungan yang mencakup keputusankeputusan (kebijakan) atau pilihan-pilihan berbagai alternatif sumberdaya untuk mencapai tujuan-tujuan pada masa yang akan datang. ( dalam jurnal arif suudi dan Djoko suwandono 2015: 52). Menurut Mardikanto (2010) tahapan perencanaan program sebagai adalah pengumpulan data keadaan, Analisis data keadaan, identifikasi masalah, pemilihan masalah yang akan dipecahkan, perumusan tujuan-tujuan, perumusan alternatif pemecahan masalah, perumusan cara mencapai tujuan, pengesahan program, rencana evaluasi, Rekonsiderasi. Secara umum prinsip perencanaan menurut Abe dalam Ovalhanif (2009) adalah Apa yang akan dilakukan, 


$\begin{array}{ll}\text { Volume } & : 06 \\ \text { Nomor } & : 02 \\ \text { Bulan } & : \text { Mei } \\ \text { Tahun } & : 2020 \\ \text { http } & : / / \text { ejurnal.pps.ung.ac.id/index.php/AKSARA/index }\end{array}$

bagaimana mencapai hal tersebut, siapa yang melakukan, lokasi aktivitas, kapan akan dilakukan, dan sumber daya yang dibutuhkan.

Dalam hal ini, tahapan perencanaan yang diterapkan oleh Desa Wisata Hutan Mangrove Desa Bedono adalah: (1) Identifikasi Permasalahan Desa BedonoPermasalahan utama yang menjadi kendala yang ada diwilayah Desa Bedono Kecamatan Sayung Kabupaten Demak Provinsi Jawa Tengah adalah semakin tingginya permukaan air asin atau abrasi air laut (ROB) sehingga mengakibatkan rusaknya lahan perkampungan serta rusaknya lahan pertanian tambak udang dan ikan yang mengakibatkan hasil panennya kurangnya maksimal maka dengan ini prioritas utama adalah untuk menanggulangi bencana abrasi air laut(ROB) tersebut yaitu Pemerintah pusat supaya secepat mungkin merealisasikan pembuatan tanggul laut atau sebutan lain jalan untuk penahan abrasi air laut (ROB) dan untuk ases jalan pinggir laut. (2) Perumusan alternatif pemecahan masalah Desa Wisata HutanMangrove Desa Bedono, Desa Bedono memiliki masalah terkait dengan masalah lingkungan yaitu masalah abrasi yang selama ini sudah menenggelamkan dua dukuh. Dengan adanya permasalahan utama di Desa Bedono yaitu Abrasi, maka pada tahun 2004 Desa Bedono dipilih dari Kabupaten dan Kecamatan Sayung untuk bekerjasama dengan organisasi dari Jepang yaitu OISCA Jepang. OISCA Jepang adalah organisasi internasional yang berpusat di jepang dan memiliki banyak cabang yang tersebar di berbagai Negara terutama kawasan Asia Pasifik dan Amerika Latin, yang bertujuan untuk meningkatkan semangat untuk generasi muda, menjaga lingkungan hidup dan pembangunan masyarakat. Desa Bedono bekerjasama dengan OISCA Jepang dengan program penanaman pohon mangrove untuk menyelamatkan Desa dari abrasi.Untuk mendukung program tersebut, dibentuklah kelompok tani yang disebut dengan Kelompok Mangrove Bahari, yang beranggotakan masyarakat Bedono.(3) Strategi penentuan cara untuk pencapaian tujuandalam melaksanakan proses perencanaan pembangunan dilaksanakan berdasarkan asas Button Up atau perencanaan berdasarkan usulan yang berasal dari masyarakat berdasarkan skala prioritas, hal ini dilaksanakan dengan melaksanakan Musyawarah Rencana Pembangunan Desa (Musrenbangdes) serta mengadakan Musyawarah Desa (Musdes) yang dilaksanakan untuk mendapatkan masukan dan skala prioritas dalam pembangunan. (Atmoko, 2014: 146) menyatakan bahwa dengan perencanaan yang dibuat dalam program Desa Wisata, tidak hanya mempertahankan ekonomi tetapi juga menjaga kelestarian lingkungan Desa.

\section{Tahapan Pelaksanaan Program Desa Wisata Hutan Mangrove Desa Bedono}

Pelaksanaan Desa Wisata Hutan Mangrove Desa Bedono dilaksanakan penuh oleh masyarakat Desa Bedono.Tahap pelaksanaan mengacu pada pengelolaan pariwisata berbasis masyarakat yang disebut dengan Community Based Tourism. Rosita Desiati (2013:258) mengemukakan Pelaksanaan ialah fungsi pengelolaan secara kompleks serta mencakup ruang lingkup yang luas dan sangan berkesinambungan dengan sumber daya manusia atau masyarakat.

(Dalam jurnal Neno Rizkianto dan Topowijono) Menurut Hudson dan Timothy dalamSunaryo (2013:139) pariwisata berbasismasyarakat atau community 


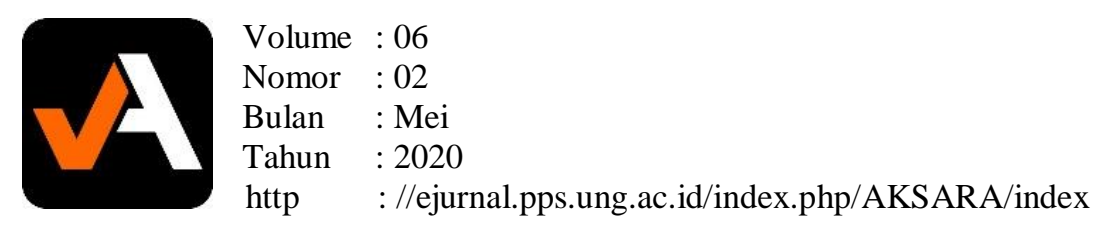

based tourismmerupakan pelibatan masyarakat dengankepastian manfaat. yang diperoleh olehmasyarakat melalui upaya perencanaanpendampingan yang membela masyarakat lokal (1) Partisipasi Masyarakat LokalPartisipasi yang diterapkan dalam pengelolaan desa wisata menggunakan partisipasi masyarakat secara spontan (spontaneous participation). Ciri-ciri partisipasi spontan ini bahwa inisiatif berasal dari masyarakat (bottom up).Hal ini dibuktikan pada tahap penyadaran menjelaskan awal mula penyadaran masyarakat Desa Wisata Bangun bersumber dari inisiatif/ide beberapa kelompok masyarakat lokal yang memiliki kesadaran bahwa Desa Bangun memiliki peluang untuk dikembangkan sektor pariwisatanya.Partisipasi spontan juga ditandai dengan masyarakat terlibat sebagai pembuat keputusan yang dibuktikan dalam pembentukan kelembagaan dan pengelolaan daya tarik wisata yang ada, seluruh komponen masyarakat Desa Wisata Bangun terlibat dan punya peran masing-masing sesuai kapasitasnya. (2) Pembentukan Kelembagaan Desa Wisata, Kelembagaan Desa Wisata Bangun telah menjalankan tugasnya berdasarkan fungsi kepemimpinan, kemitraan internal, pengembangan daya tarik wisata dan peningkatan Sumber Daya Manusia. Hal ini membuktikan bahwa fungsi kelembagaan sudah berjalan.Bagus Kisworo (2014:46) mengemukakan dengan dibentuknya suatu kelompok masyarakat adalah mendukung suatu kegiatan/program masyarakat agar bisa mencapai tujuan program yang merupakan keinginan masyarakat agar bisa tercapai.

Desa Wisata Hutan mangrove membentuk suatu kelompok yang mengelola Desa Wisata seperti kelompok mangrove dan POKDARWIS Bedono.Masyarakat berperan aktif dalam pengelolaan Desa Wisata Hutan Mangrove Desa Bedono. (3) Pengelolaan Daya Tarik Wisata Berwawasan Lingkungan, Pengelolaan daya tarik Desa Wisata Hutan Mangrove Desa Bedono diarahkan ke pada wisata berwawasan lingkungan. Hal ini dibuktikan dengan adanya pembagian zonasi wilayah yang terdiri dari zona inti, zona pendukung dan zona ekonomi.Selain itu pihak pengelola juga memberikan banyak arahan untuk menjaga faslitas yang ramah lingkungan. (4) Terciptanya Kegiatan Usaha Masyarakat, Secara keseluruhan dari kegiatan usahamasyarakat yang ada, dikelola oleh masyarakat sendiri.

Masyarakat Desa Bedono sangat bersemangat dalam membangun Desanya.Dari awal program, masyarakat sudah berpartisipasi aktif dalam program penanaman.Setelah dibentuk Kelompok Mangrove jumlah pengurusnya ada 5 orang dan anggotanya ada 20 orang.Setelah itu berlanjut pada pengelolaan wisata, dimana semua peran diambil alih oleh masyarakat Desa Bedono.Pengelolaan dari parkir, ojek perahu, dan pedagang yang ada di Desa Wisata Hutan Mangrove Desa Bedono adalah masyarakat Desa Bedono.

Tahap pelaksanaan menjadi suatu hal yang penting untuk mengukur keberhasilan suatu program, maka pada tahapan pelaksanaan perlu adanya pengawasan agar mencapai tujuan yang sudah ditetapkan bersama. Tahapan ini memutuhkan konsistensi dan kerjasama dari semua stakeholder yang berperan dalam mensukseskan program desa wisata dengan membangun komunikasi dan kerjasama yang baik, sehingga setiap unsur atau elemen yang terlibat didalamnya dapat melaksanakan tugas dan fungsinya agar tujuan dari program desa wisata dapat tercapai.Untuk pelaksanaan 


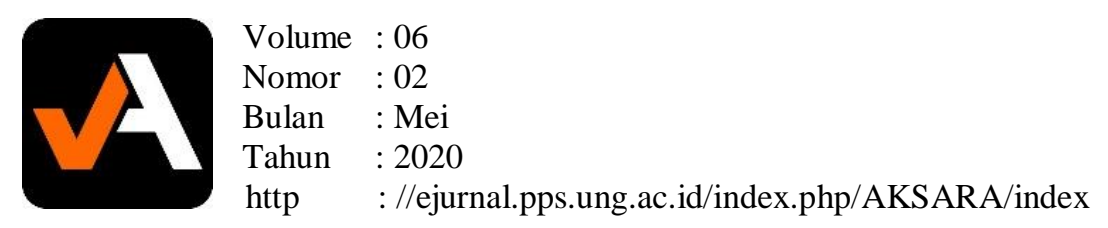

Desa Wisata Hutan Mangrove Desa Bedono, dimulai dari program penanaman, Desa Wisata Hutan Mangrove Desa Bedono bekerjasama dengan organisasi OISCA dari jepang yang membantu dalam hal pelaksanaan penanaman pohon mangrove. Perihal bekerjasama ada ketentuan-ketentuan yang diberikan, seperti kontrak program 5 tahun 1 periode nya, diadakannya monitoring dari kabupaten, dan ketentuan penanaman pohon yang akan ditanam.

Pemerintah Daerah mendukung Desa Wisata Hutan Mangrove Desa Bedono menjadi Desa Wisata dengan dukungan diperbaikinya akses jalan menuju Desa Wisata Hutan Mangrove Desa Bedono. Desa Wisata Hutan Mangrove Desa Bedono sudah menyiapkan fasilitas yang baik untuk wisatawan dan semua fasilitas dikelola oleh masyarakat. (5) Kunjungan Wisatawan Desa Wisata Hutan Mangrove Desa Bedono, Desa Wisata Hutan Mangrove Desa Bedono mempunyai beragam pilihan wisata. Dari wisata Religi, Spot foto yang indah dan juga wisata air. Untuk kunjungan Wisatawan Hutan Mangrove Desa Bedono bisa ditujukan ke semua lapisan masyarakat.Dari anakanak hingga dewasa, bergantung pada tujuan yang ingin dituju.Untuk tiket masuk hanya disiapkan kotak amal untuk perawatan Desa Wisata Hutan Mangrove Desa Bedono, untuk parkir hanya Rp. 2000 untuk sepeda motor.

Peraturan yang diterapkan di Desa Wisata Hutan Mangrove Desa Bedono adalah menggunakan pakaian yang sopan dan menjaga lisan saat berada disana.Sedangkan perizinan mengamil gambar, juga ada peraturannya. Jika membawa handphone diperbolehkan secara bebas, tetapi jika membawa kamera harus izin terlebih dahulu, dengan membayar sesuai dengan tujuan pengambilan gambar dan akan mendapat Kartu izinnya. (6) Pendanaan Desa Wisata Hutan Mangrove Desa Bedono, Desa Wisata Hutan Mangrove Desa Bedono semua kegiatan yang dilakukan untuk pengelolaan dilakukan seara mandiri. Tetapi juga mendapatkan dana dari berbagai Instansi , Donatur, Sponsor, swadaya dan juga Sumber PAD. (7) Paket Kegiatan Desa Wisata Hutan Mangrove Desa Bedono, Kegiatan berwisata berlangsung karena mempunyai beberapa faktor, salah satu di antaraya adalah faktor daya tarik wisata yang ada di destinasi wisata. Menurut Undang-Undang Kepariwisataan Nomor 10 Tahun 2009, daya tarik wisata adalah segala sesuatu yang memilik keunikan, keindahan, dan nilai yang berupa keanekaragaman kekayaan alam, budaya, dan hasil buatan manusia yang menjadi sasaran atau tujuan kunjungan wisatawan. (8)Fasilitas Desa Wisata Hutan Mangrove Desa Bedono dari hasil penelitian di lapangan Desa Wisata Hutan Mangrove Desa Bedono memiliki fasilitas yang baik dan mendukung kenyamanan wisatawan yang berkunjung ke Desa Wisata Hutan Mangrove Desa Bedono. Hal ini dijelaskan pada peraturan UU No. 6 tahun 2014 yang didalamnya pada pasal 18 dimana desa memiliki kewenangan di bidang penyelenggaraan pemerintahan, pembangunan desa, pembinaan kemasyarakatan, dan pemberdayaan masyarakat desa. (9) Sarana dan Prasarana Desa Wisata Hutan Mangrove Desa Bedono, Sarana wisata adalah tempat yang sangat unik dan menarik untuk wisatawan. Desa Wisata Hutan Mangrove Desa Bedono mempunyai wisata religi, wisata air, hingga spot foto yang menarik untuk wisatawan. Disediakannya penyewaan perahu menuju hutan mangrove yang berada di tengah laut.Sering menjadi keluhan wisatawan terhadap Desa Wisata adalah minimnya 


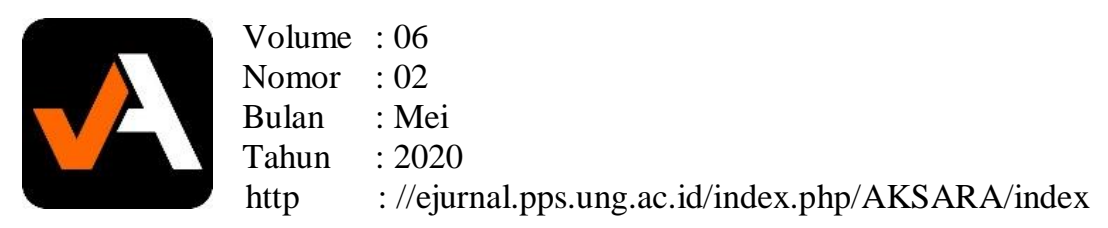

kondisi sarana wisata yang disediakan, padahal sarana wisata adalah salah satu faktor penentu kepuasan (Soeiyantoro, 2009).Dengan ini, Desa Wisata Hutan Mangrove Desa Bedono menyediakan sarana yang lengkap untuk memberikan kepuasan para wisatawan yang datang. Prasarana wisata adalah sumer daya alam dan sumer daya buatan yang diutuhkan oleh wisatawan dalam perjalanan menuju daerah tujuan wisatanya seperti jalan, listrik, air, telekomunikasi, jembatan, parkir, dan lain seagainya. Untuk pengelolaan dari segi prasarana Desa Wisata Hutan Mangrove Desa Bedono seagaimana yang telah dirangkum oleh peneliti dalam wawanara dan dokumentasi, Desa Wisata Hutan Mangrove Desa Bedono memiliki prasarana wisata yang baik.

Akses jalan, listrik, air, telekomunikasi, lahan parkir sudah ada di Desa Wisata Hutan Mangrove Desa Bedono.Akses jalan menuju Desa Wisata Hutan Mangrove Desa Bedono sudah merupakan jalan beton.Untuk listrik sudah tersedia dengan baik, semua rumah sudah dialiri listrik, telekomunikasi disana sudah terjangkau mendapat sinyal untuk berkomunikasi.Ketersediaan air bersih juga sudah ada disana. Jadi prasarana Desa Wisata Hutan Mangrove Desa Bedono sudah sangat baik dan nyaman untuk wisatawan yang akan datang.

\section{Pengawasan Program Desa Wisata Hutan Mangrove Desa Bedono}

(Dalam jurnal devi dan mulyono ) Menurut pendapat Daman (2012 : 15) monitoring dan evaluasi adalah suatu proses kegiatan untuk menentukan keberhasilan suatu program. Keberhasilan dapat dilihat dari apa yang diperoleh, kesesuaian antara hasil perencanaan dengan pelaksanaan . Penilaian atau evaluasi dilakukan ada tiga tahap yaitu: (1) Tahap awal kegiatan, Evaluasi awal dimulai saat menentukan fokus dan jenis kegiatan yang akan dilaksanakan. Setelah penentuan fokus dan jenis kegiatan, petugas monitoring dan evaluasi mengevaluasi dari tingkat kesesuaian dan daya dukung. (2) Tahap proses yaitu pada saat proses perjalanan pelaksanaan kegiatan Desa Wisata Hutan Mangrove Desa Bedono bergeser atau tidak. (3) Evaluasi akhir dilakukan dengan penyusunan laporan, untuk mengetahui sejauh mana keberhasilan dari Desa Wisata Hutan Mangrove Desa Bedono.

Sedangkan pelaksanaan Monitoring dilaksanakan dengan beberapa langkah, langkah pertama melakukan kegiatan perencanaan program, langkah dan prosedur serta komponen isi yang akan dimonitoring dan dievaluasi disiapkan dengan baik, kedua yaitu pelaksanaan kegiatan monitoring dan evaluasinya itu sendiri, dan yang ketiga pelaporan hasil kegiatan dalam bentuk laporan tertulis sebagai bahan untuk evaluasi. Tujuan kegiatan monitoring dan evaluasi adalah memberikan pemahaman dalam pengawasan terhadap kegiatan program Desa Wisata Hutan Mangrove Desa Bedono, mengetahui keberhasilan program, mengidentifikasi faktor-faktor pendukung dan penghambat, memberikan masukan untuk penyempurnaan pelaksanaan program.Pengawasan Desa Wisata Hutan Mangrove Desa Bedono dilaksanakan 1 bulan sekali pelaporan dan monitoring dari Pemerintah Desa Bedono dengan BPD, setiap 3 bulan sekali monitoring dari koordinator OISCA Kabupaten, serta evaluasi setiap 1 tahun sekali dari DKP pusat dan Kabupaten. Pengawasan ini dilaksanakan 


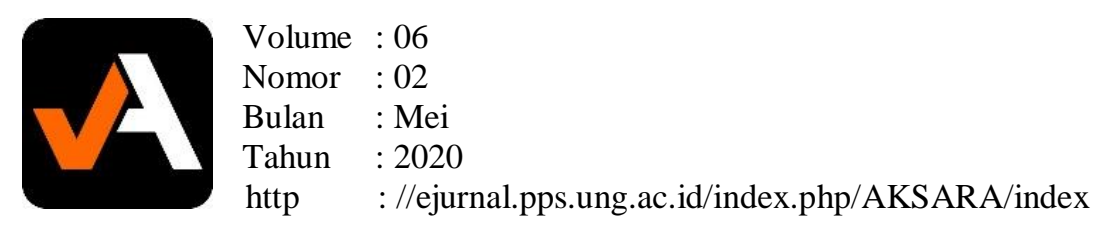

dengan pihak-pihak yang mendukung dan bekerjasama dalam pengelolaan Desa Wisata Hutan Mangrove Desa Bedono. Monitoring dan Evaluasi yang dilaksanakan oleh OISCA Jepang ada beberapa fokus yaitu, fokus pencatatan data, fokus penghitungan (Counting), fokus penanaman (Planting) dan fokus pemberantasan hama.

\section{Pembahasan}

\section{Tahap Perencanaan Desa Wisata Hutan Mangrove Desa Bedono}

Menurut Mardikanto (2010) tahapan perencanaan program sebagai adalah pengumpulan data keadaan, Analisis data keadaan, identifikasi masalah, pemilihan masalah yang akan dipecahkan, perumusan tujuan-tujuan, perumusan alternatif pemecahan masalah, perumusan cara mencapai tujuan, pengesahan program, rencana evaluasi, Rekonsiderasi. Perencanaan Pengelolaan Desa Wisata Hutan Mangrove Desa Bedono diawali dengan mengidentifikasi kebutuhan masyarakat Desa Bedono. Perencanaan tersebut dibuat melaui Musyawarah Desa (MUSDES) untuk menetapkan rencana yang akan dilaksanakan.

Desa Bedono mempunyai permasalahan yang terbesar yaitu mengenai Abrasi (ROB). Pemerintah Desa Bedono terus mencari jalan keluar untuk menyelamatkan Desa Bedono dari Abrasi. Dengan hal ini, Pemerintah Desa Bedono mendapatkan tawaran bekerjasama dengan Organisasi Jepang yang bernama OISCA Jepang dengan tujuan penanaman pohon Mangrove di pesisir pantai untuk menanggulangi adanya Abrasi (ROB) di Desa Bedono.

Menurut Beishline (1957), perencanaan menetapkan apa yang hendak di wujudkan, dimana, serta bagaimanacara agar tercapai, siapa yang terlibat dalam hal ini, dan mengapa tujuanitu harus di gapai. Heni (2013:131) mengemukakan bahwa Desa wisata adalah bentuk pelaksanaan pembangunan wisata berbasis masyarakat secara berkelanjutan. Dengan adanya Desa Wisata akan menjadi produk wisata lebih bernilai dengan budaya desa tanpa merusaknya. Ada satu hal yang dapat memberikan kesan untuk menciptakan suatu daerah wisata adalah disesuaikan adat istiadat budaya lokal di daerah tersebut. Keadaan ini yang menjadikan dibentuknya kegiatan wisata di suatu desa karena ciri khas adat istiadat warga yang tinggal di lingkungan tersebut.

Desa Bedono mempunyai tingkat partisipasi masyarakat yang tinggi. Dengan ini, Desa Wisata Hutan Mangrove Desa Bedono memulai dari penetapan tujuan telah melibatkan masyarakat Desa Bedono. Dalam melaksanakan proses perencanaan pembangunan dilaksanakan berdasarkan asas Button Up atau perencanaan berdasarkan usulan yang berasal dari masyarakat berdasarkan skala prioritas, hal ini dilaksanakan dengan melaksanakan Musyawarah Rencana Pembangunan Desa (Musrenbangdes) serta mengadakan Musyawarah Desa (Musdes) yang dilaksanakan untuk mendapatkan masukan dan skala prioritas dalam pembangunan. Yang mana, Desa Wisata Hutan Mangrove Desa Bedono mempunyai tujuan untuk menyelamatkan Desa Bedono dari Abrasi dan memajukan Desa Bedono, serta meningkatkan perekonomian masyarakat Desa Bedono.

Ada beberapa tujuan perencanaan Robbins dan Coulter (2009) mengemukakan bahwa : (1) adalah memberikan pengarahan, petunjuk atau pedoman, untuk pengelola 


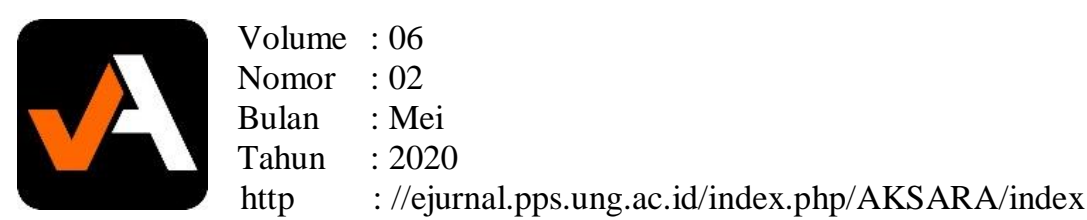

maupun karyawan non manajerial. Dengan rencana, manajer dan anggota dapat mengetahui apa saja yang harus mereka gapai, bagaimana cara mencapainya, apa yang harus dikerjakan, peralatan yang akan digunakan, dengan siapa saja harus membangun relasi, serta apa yang harus dilakukan agar dapat menggapai tujuan kelompok. Dengan adanya pengarahan yang tertuang dalam rencana tersebut, setiap karyawan bisa bekerja tanpa harus menunggu perintah sehingga tidak membuang-buang waktu. Tanpa rencana, divisi dan karyawan dengan cara individu akan bisa melakukan pekerjaan sendiri-sendiri dengan cara sembarangan, tidak terjadwal, tidak ada pedoman yang jelas sehingga hasil kerja karyawan maupun organisasi kurang efesien. (2) mengurangi ketidakjelasan yang berhubungan dengan masa yang depan. Rencana digunakan untuk waktu kedepan yang penuh ketidakpastian sehingga sarat dengan ramalan-ramalan (forecast). Oleh karena itu, kepastian yang dibuat dan dituangkan dalam suatu rencana tergantung dari kepekaan para manajer dalam melakukan forcasting. Saat pengelola membuat perencanaan, mau tidak mau harus memandang kedepannya, mempunyai pandangan suatu perbedaan, membuat perkiraan dampak dari perubahan tersebut, menetapkan waktu pelaksanaan, dan pembuatan perencanaan untuk di selesaikan dimasa depan. Tanpa rencana, mereka akan bekerja tanpa target, baik kualitas maupun kuantitas, dan untuk jangka waktu baik yang lihat karesud pak ran bah pul yang tidak pasti, (3) adalah mengurangi adanya penggunaan sesuatu secara lebih, dari jam, uang, ataupun kekuatan yang digunakan untuk menjadikan suatu barang atau apapun. Dengan kerja yang mempunyai arah dan rencana yang jelas, semua karyawan dapat bekerja lebih pasti dan lebih efesien sehingga dapat mengurangi terjadinya pemborosan. Pemborosan mungkin terjadi di berbagai bidang kerja, seperti bidang produksi, pemasaran, administrasi, personalia, dan keuangan se- kalipun. Pemborosan terhadap sumber daya-sumber daya yang di- miliki oleh organisasi, berupa pemborosan waktu, biaya, maupun tenaga. Selain itu, dari perencanaan, seorang pengelola bisa mengidentifikasi serta mengurangi hal-hal yang bisa menimbulkan kon sasi sua tetalinefesiensi dalam perusahaan. (4) adalah menentukan tujuan serta standar yang sesuai dengan manfaat selanjutnya, ialah proses pengawasan dan evaluasi . Proses evaluasi adalah merupakan perbandingan suatu yang di rencanakan dengan apa yang telah dilaksanakan serta hasil apa yang telah ada.

Konsep pengelolaan Desa Wisata Hutan Mangrove Desa Bedono telah dirancang dengan konsep wisata berbasis masyarakat. Menurut (Hayati dan Darmawi, 2010) Wisata berfokus pada warga atau Community Based Tourism (CBT), ialah manajemen wisata yang mempunyai tahap partisipasi warga lokal yang tinggi serta mampu dipercaya dari ranah sosial maupun perekonimiannya. Wahyuningtyas (2018:76) mengemukakan tujuan Community Based Tourism (CBT) adalah agar memperbaiki dan memberikan kekuatan maupun keahlian untuk warga setempat.

Model Pengelolaan Desa Wisata Hutan Mangrove Desa Bedono menggunakan Model Community Based Tourism (CBT) dimana masyarakat Desa Bedono berperan aktif dalam proses pengelolaan dari perencanaan, pelaksanaan, maupun pengawasannya. 


$\begin{array}{ll}\text { Volume } & : 06 \\ \text { Nomor } & : 02 \\ \text { Bulan } & : \text { Mei } \\ \text { Tahun } & : 2020 \\ \text { http } & : / / \text { ejurnal.pps.ung.ac.id/index.php/AKSARA/index }\end{array}$

\section{Tahap Pelaksanaan Program Desa Wisata Hutan Mangrove Desa Bedono}

Kebijakan ialah pegangan pelaksanaan untuk tindakan yang sesuai dengan cara meraih suatu tujuan dan sasaran. Kebijakan berbentuk aturan di bidang publik, teknis, alokasi sumber-daya kelompok, pelayanan masyarakat, antara lain adalah :

1. wewenang/tanggung jawab pengelola

2. Dokumentasi beragam pola kerja untuk tiap tahapan pengelolaan yangmana revisi penyebaran ataupun dibatalkan agar dimudahkan tindakan yang dicek dan juga mencegah yang tidak diginkan.

3. Koordinasi secara dalam dan luar.

4. Pengadaan (prourement)

5. Mengendalikan tahap supaya keluaran sesuai dengan perencanaan dan tingkat target (yang termasuk: instruksi tugas, sarana-prasarana, perawatan,lingkungan kerja).

6. Inspeksi, menguji dan tindakan dicek maupun mengurangi hal-hal yang tidak diinginkan.

7. Pelatihan staff agar meningkatkan kedisiplinan dan keahliannya.

8. Jaminan pelayanan prima (kebijakan publik).

9. Dibutuhkan chek list kelengkapan aturan kelompok tersebut (Akdon, 2011 : 187).

Desa Wisata Hutan Mangrove Desa Bedono memiliki berbagai pilihan wisata, yaitu wisata Religi, wisata air, dan wisata Hutan Mangrove. Untuk menentukan sasaran wisatawan Desa Wisata Hutan Mangrove Desa Bedono adalah seluruh lapisan masyarakat lokal maupun mancanegara. Semua masyarakat diperbolehkan mengunjungi Desa Wisata Hutan Mangrove Desa Bedono dengan menaati peraturan yang telah ditetapkan. Seperti, mengenakan pakaian yang sopan, tidak menyalahgunakan tempat wisata untuk hal-hal yang tidak di inginkan, menjaga kebersihan lingkungan, berperilaku sopan.

Desa Wisata Hutan Mangrove Desa Bedono semua kegiatan yang dilakukan untuk pengelolaan secara mandiri. Tetapi juga mendapatkan dana dari berbagai Instansi , donatur, sponsor, swadaya dan juga Sumber PAD. Desa Wisata Hutan Mangrove Desa Bedono bekerjasama dengan pihak-pihak yang mampu membantu masyarakat dan pemerintah Desa untuk mengelola potensi Desa yang ada sehingga dapat berinvestasi untuk masa depan masyarakat.

Sarana wisata adalah tempat yang sangat unik dan menarik untuk wisatawan. Desa Wisata Hutan Mangrove Desa Bedono mempunyai wisata religi, wisata air, hingga spot foto yang menarik untuk wisatawan. Disediakannya penyewaan perahu menuju hutan mangrove yang berada di tengah laut. Sering menjadi keluhan wisatawan terhadap Desa Wisata adalah minimnya kondisi sarana wisata yang disediakan, padahal sarana wisata adalah salah satu faktor penentu kepuasan (Soeiyantoro, 2009).

Dengan ini, Desa Wisata Hutan Mangrove Desa Bedono menyediakan sarana yang lengkap untuk memberikan kepuasan para wisatawan yang datang. Prasarana wisata adalah sumber daya alam dan sumer daya buatan yang dibutuhkan oleh 
wisatawan dalam perjalanan menuju daerah tujuan wisatanya seperti jalan, listrik, air, telekomunikasi, jembatan, parkir, dan lain sebagainya.

Akses jalan, listrik, air, telekomunikasi, lahan parkir sudah ada di Desa Wisata Hutan Mangrove Desa Bedono. Akses jalan menuju Desa Wisata Hutan Mangrove Desa Bedono sudah merupakan jalan beton. Untuk listrik sudah tersedia dengan baik, semua rumah sudah dialiri listrik, telekomunikasi disana sudah terjangkau mendapat sinyal untuk berkomunikasi. Ketersediaan air bersih juga sudah ada disana. Jadi prasarana Desa Wisata Hutan Mangrove Desa Bedono sudah sangat baik dan nyaman untuk wisatawan yang akan datang.

\subsubsection{Tahap Pengawasan Desa Wisata Hutan Mangrove Desa Bedono}

Tahap paling akhir dari tahapan manajemen adalah pengawasan. Pengawasan bermaksud mengamati apakah kegiatan kelompok sesuai dengan rencana. Pengelola wajib mengawasi kemajuan kelompok. Nurhalim (2014:49) mengemukakan evaluasi adalah suatu proses untuk mengumpulkan dan menganalisis data atau informasi agar dapat mengetahui tingkat pencapaian tujuan suatu kegiatan/program. Mulyono (2015:88) Evaluasi dan monitoring adalah suatu program yang dilaksanakan guna mengetahui program dengan terencana serta untuk mengetahui tingkat kesuksesan suatu program.

Fungsi pengendalian ada bebeberapa kegiatan: (1) menentukan tingkat prestasi, (2) melakukan pengukuran prestasi yang sudah di dapat selama ini, (3) memberikan perbandingan prestasi yang sudah tercapai dengan target prestasi, dan (4) melaksanakan perbaikan bila ada penyalahgunaan tingkat prestasi yang sudah ditentukan. Lalu, akan kembali dari fungsi perencanaan untuk periode berikutnya (Mamduh Hanafi : 2015).

Pengawasan Desa Wisata Hutan Mangrove Desa Bedono dilaksanakan 1 bulan sekali pelaporan dan monitoring dari Pemerintah Desa Bedono dengan BPD, setiap 3 bulan sekali monitoring dari koordinator OISCA Kabupaten, serta evaluasi setiap 1 tahun sekali dari DKP pusat dan Kabupaten. Pengawasan ini dilaksanakan dengan pihak-pihak yang mendukung dan bekerjasama dalam pengelolaan Desa Wisata Hutan Mangrove Desa Bedono.

Pengawasan dari pihak Desa lebih fokus pada pengelolaan Desa Wisata Hutan Mangrove dari tahap perencanaan sampai ke pelaksanaan, dengan adanya musyawarah Desa yang sering diadakan untuk melibatkan masyarakat dalam pengelolaan Desa Wisata Hutan Mangrove Desa Bedono serta bertanggungjawab dengan tugas yang sudah diberikan pada masyarakat, sedangkan dari OISCA jepang berfokus pada penanaman Pohon Mangrove-nya, dari segi data maupun lapangan. Monitoring dan Evaluasi yang dilaksanakan oleh OISCA Jepang ada beberapa fokus yaitu, fokus pencatatan data, fokus penghitungan (Counting), fokus penanaman (Planting) dan fokus pemberantasan hama. 


$\begin{array}{ll}\text { Volume } & : 06 \\ \text { Nomor } & : 02 \\ \text { Bulan } & : \text { Mei } \\ \text { Tahun } & : 2020 \\ \text { http } & : / / \text { ejurnal.pps.ung.ac.id/index.php/AKSARA/index }\end{array}$

\section{Simpulan dan Saran}

Perencanaan program Desa Wisata Hutan Mangrove perencanaan berdasarkan usulan dan kesepakatan masyarakat sesuai dengan skala prioritas kebutuhan Desa Bedono. Perencanaan Desa Wisata Hutan mangrove Desa Bedono menerapkan beberapa tahapan dalam perencanaan program yaitu yang pertama, identifikasi permasalahan Desa Bedono yaitu permasalahan mengenai Abrasi (ROB) yang terjadi di Desa Bedono hingga menenggelamkan 2 Dukuh sehingga harus relokasi ke Desa lain. Yang kedua, perumusan alternatif permasalahan Desa Wisata Hutan Mangrove Desa Bedono, yang mana salah satu jalan untuk menyelamatkan Desa Bedono adalah dengan penanaman Pohon Mangrove, untuk penanaman Desa Bedono bekerjasama dengan organisasi dari Jepang yang bernama OISCA dengan tujuan menjaga lingkungan Hidup dan pembangunan Masyarakat. Yang ketiga adalah tahap strategi penentuan cara untuk mencapai tujuan, yang mana masyarakat memilih untuk memajukan desa dengan cara meningkatkan partisipasi masyarakat Desa Bedono. Dapatdisimpulkan bahwa perencanaan Desa Bedono dengan Desa Wisata berbasis masyarakat lokal.

Pelaksanaan program Desa Wisata Hutan Mangrove Desa Bedono dilaksanakan sesuai dengan apa yang telah direncanakan yaitu pengelolaan Desa Wisata berbasis masyarakat lokal. Untuk melaksanakan perencanaan Desa Wisata Hutan Mangrove berbasis masyarakat ada beberapa tahapan pelaksanaan yang diterapkan oelh Desa Wisata Hutan Mangrove Desa Bedono, yaitu yang pertama partisipasi masyarakat lokal dimana masyarakat berperan aktif dalam pelaksanaan program Desa Wisata Hutan Mangrove Desa Bedono. Yang kedua adalah pembentukan kelembagaan Desa Wisata dengan adanya Kelompok Mangrove dan POKDARWIS Desa Bedono yang mempunyai tugas masing-masing. Yang ketiga adalah tahap pengelolaan daya tarik wisata berwawasan lokal, dengan menerapkan kekayaan lingkungannya Desa Wisata Hutan Mangrove mempunyai berbagai pilihan wisata, dari Hutan Mangrove, Wisata Religi dan Wisata air yang telah disediakan disana. Yang keempat adalah terciptanya kegiatan usaha masyarakat, masyarakat Desa Bedono memanfaatan lahan yang mereka punya untuk berdagang makanan khas Desa Bedono yaitu Keripik Mangrove dan juga lahan-lahan untuk tempat parkir, serta penyewaan perahu oleh masyarakat Desa Bedono.

Pengawasan dilaksanakan dari berbagai pihak yang terkait dalam program Desa Wisata Hutan Mangrove Desa Bedono. Yang pertama ada pengawasan dari OISCA Jepang yaitu monitoring 3 bulan sekali mengenai pohon mangrove yang ditanam, ada evaluasi 1 tahun sekali untuk perbaikan kedepan. Yang kedua ada pengawasan dari pihak Desa yang mengawasi tentak pelaksanaan Desa Wisata Hutan Mangrove Desa Bedono, bagaimana tingkat partisipasi masyarakat, penjagaan lingkungan, dan pembangunan masyarakat Desa Bedono.

Dalam hal pengelolaan Desa Wisata Hutan Mangrove Desa Bedono sangat bagus dalam tingkat partisipasi masyarakatnya, tetapi seharusnya bisa dibentuk pengorganisasian untuk fokus mengelola Desa Wisata Hutan Mangrove Desa Bedono secara jelas. Agar kedepannya Desa Wisata Hutan Mangrove Desa Bedono semakin 


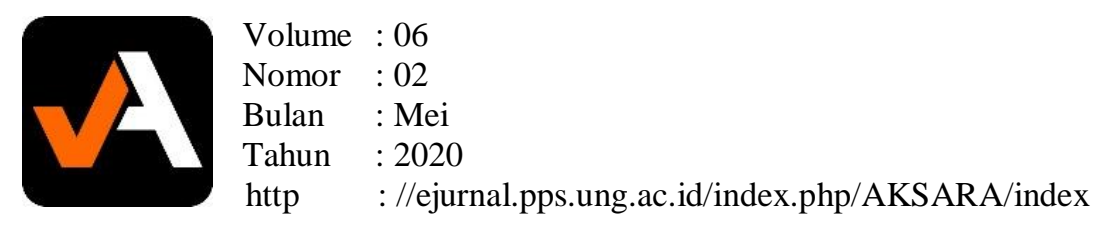

baik, maju dan menjadi Desa percontohan untuk Desa lain. Melakukan promosi yang lebih semangat untuk semakin memajukan Desa Wisata Hutan Mangrove di semua kalangan Masyarakat lokal maupun mancanegara.

\section{DAFTAR PUSTAKA}

Aditya Eka, H. W. (2018). Pembangunan Desa Wisata dan Pemberdayaan Masyarakat Berbasis Potensi Lokal. Jurnal Pendidikan , 29-33.

Akdon. (2011). Strategic Management for Educational Management. Bandung: Alfabeta.

Andini, N. (2013). Pengorganisasian komunitas dalam pengembangan agrowisata di Desa Wisata Studi Kasus : Desa Wisata Kembangarum, Kabupaten Sleman. Jurnal Perencanaan Wilayah dan Kota, Vol. 24 No. 3, , 175.

Angelina Vita, A. Y. (2013). Manajemen dalam konteks Indonesia. Yogyakarta: Kanisius.

Arif Su'udi, D. S. (2015). perenanaan konsep pengelolaan dan pemiayaan pembangunan kawasan wisata hutan mangrove desa Bedono kecamatan Sayung Kaupaten Demak. Jurnal Ruang Volume 1 Nomor 2 , 52-53.

arikunto, s. (2006). Metode Penelitian. Yogyakarta: Bina Aksara.

Atmoko, T. P. (2014). strategi pengembangan potensi Desa Wisata Brajan Kabupaten Sleman. Jurnal Media Wisata, 146.

Bagus Kisworo, N. S. (2014). Partisipasi pemuda dalam program Karang Taruna Desa (Studi Pada Pemuda di Dusun Kupang Kidul Desa Kupang

Imam, S. (2014). Pengembangan Masyarakat berbasis Sumber Daya Lokal. Yogyakarta: Pustaka Belajar.

Saktywati, S., Sutarto, J., \& Mulyono, S. E. (2013). Kewirausahaan Masyarakat melalui Desa Vokasi di Desa Gemawang Kecamatan Jambu Kabupaten Semarang. Journal of Nonformal Education and Community Empowerment, 2(1), 41-49.

Jr, D. B. (2018). Shifting the perspective on community-based management of education : From systems theory to social capital and community empowerment. International Journal of Educational Development , 1-8.

Muslikhah, M., \& Nurhalim, K. (2014). Penyelenggaraan program Nasional Pemberdayaan Masyarakat (PNPM) Mandiri Pedesaan Dalam peningkatan Ekonomi Petani Wanita (Studi pelatihan Penggemukan Kambing di Desa Kalimanggis Kabupaten Batang). Journal of Nonformal Education and Community Empowerment, 3(1), 47-53.

Made Heny Urmila Dewi, C. f. (2013). Pengembangan Desa Wisata Berbasis Partisipasi Masyarakat Lokal di Desa Wisata Jatiluwih Tabanan Bali. Jurnal Kawistara vol.3 , 131.

Mary Williams a, J. B. (2017). Data management plans: the missing perspective. Journal of Biomedical Informatics , 130-142.

Moleong, L. J. (2006). Metodologi Penelitian Kualitatif. Bandung: Rosdakarya. 


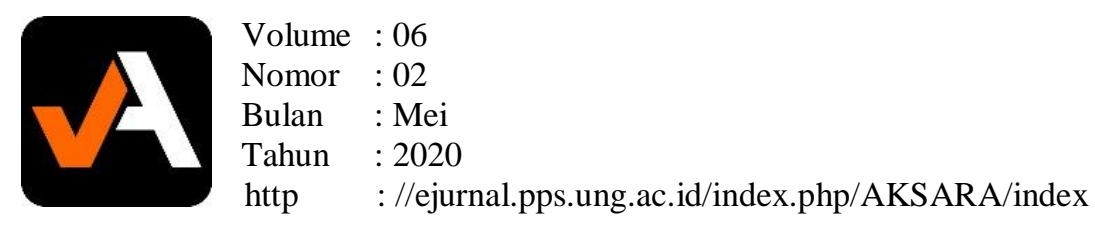

Nalayani, N. N. (2016). Evaluasi dan strategi pengembangan Desa Wisata Di Kabupaten Badung Bali. Jurnal Jumpa , 189-198.

Neno Rizkianto, T. (2018). Penerapan Community Based Tourism Dalam Pengelolaan Daya Tarik Wisata Berkelanjutan. Jurnal Administrasi Bisnis , 20-26.

Ninik Wahyuningtyas, M. D. (2018). Potensi Pengembangan Desa Kliwonan sebagai Desa Wisata Batik. Journal of Regional and Rural Development Planning , 74-89.

Priyantono, D. S. (2016). Pengembangan Potensi Desa Wisata Berbasis Budaya Tinjauan Terhadap Desa Wisata Di Jawa Tengah. Jurnal Vokasi Indonesia, 77-82.

Reny Triwardani, C. R. (2014). Implementasi Kebijakan Desa Budaya Dalam Upaya Pelestarian Budaya Lokal. Jurnal Unitri, 102-110.

Devi, K. H., \& Mulyono, S. E. (2015). Monitoring Dan Evaluasi Pelaksanaan Kewirausahaan Produk Unggulan pada Program Desa Vokasi Candi Kecamatan Bandungan Kabupaten Semarang. Journal of Nonformal Education and Community Empowerment, 4(2), 88-92.

Sangchumnong, A. (2017). Development of a sustainable tourist destination based on the creative economy: A case study of Klong Kone Mangrove Community, Thailand. Kasetsart Journal of Social Sciences , 1-8.

Sugiyono. (2016). Metode Penelitian Kuantitatif, Kualitatif, dan R\&D. Bandung: Alfabeta.

Hajaroh, L. \& Mulyono, S. E. (2014). Partisipasi anggota kelompok swadaya masyarakat dalam pengembangan Desa Wisata melalui Badan Keswadayaan Masyarakat di Kelurahan Kandri Kota Semarang. Journal of Nonformal Education and Community Development, 3(2), 31-35.

Sururi, A. (2015). Pemberdayaan Masyarakat Melalui Program Pembangunan Infrastruktur Pedesaan dalam Meningkatkan Kesejahteraan Masyarakat Kecamatan Wanasalam Kabupaten Lebak. Jurnal Sawala , 1-23.

Suseela Sreelekshmi, C. M. (2018). Diversity, stand structure, and zonation pattern of mangroves in. Journal of Asia-Pacific Biodiversity , 573-582.

Wahyurini, E.T. (2017). Pemberdayaan dan Peran Masyarakat Pesisir pada Pengembangan Mangrove menuju Ekowisata di Kabupaten Pemekasan. Jurnal Pengabdian Kepada Masyarakat, 49-53. 